\title{
PREDICTION MODEL FOR THE NUMBER OF ARI CASES IN CHILDREN IN SURABAYA USING ARIMA METHOD
}

\author{
Alvin Zulhazmi Priambodo ${ }^{1}$, Mahmudah ${ }^{2}$ \\ ${ }^{1,2}$ Department of Biostatistics and Population, Faculty of Public Health, Universitas Airlangga, 60115 Surabaya, East Java, \\ Indonesia \\ Corresponding Author: Alvin Zulhazmi Priambodo \\ E-mail: Alvin.zulhazmi.priambodo-2017@fkm.unair.ac.id
}

\begin{abstract}
Forecasting is an important element in planning decision-making related to estimating future events. Forecasting techniques that are often developed and used today are the Time Series. Time series is a measurement of events through the stages of time in hours, days, months, and years format. This research uses the ARIMA time series method. The ARIMA method is used to model acute respiratory infections (ARI) in children. The best model is determined using the smallest error through the Mean Absolute Percentage Error (MAPE). The study aims to predict the number of ARI cases in children in Surabaya. This research is an unobtrusive/nonreactive research. The researcher conditioned the subjects to not being aware that the subject is being studied and therefore, left the subject uninterrupted. The data used was the number of ARI cases in children from January 2014 to December 2018. The data was obtained from the monthly report of the Health Information System Unit (HIS) of the Surabaya City Health Office. The conclusion from this study showed that the ARIMA method obtained the best model results, namely ARIMA $(2,1,2)$ with a MAPE value of 15.024 . Forecasting results fluctuated and a downward trend in the case of ARI children in Surabaya. In certain months, the number of acute respiratory infections has increased significantly, including in February and March.
\end{abstract}

Keywords: forecasting, time series, autoregressive integrated moving average, acute respiratory infections

\begin{abstract}
ABSTRAK
Peramalan merupakan unsur penting dalam perencanaan pengambilan keputusan yang berkaitan dengan memperkirakan kejadian di masa depan. Teknik peramalan yang sering dikembangkan dan digunakan sampai saat ini yaitu Deret Waktu / Time Series. Time series merupakan pengukuran peristiwa melalui tahapan waktu berupa jam, hari, bulan dan tahun. Penelitian ini menggunakan metode time series jenis ARIMA. Metode ARIMA digunakan untuk membuat model Infeksi Saluran Pernafasan Akut (ISPA) pada anak. Model terbaik ditentukan dengan menggunakan error terkecil melalui Mean Absolute Precentage Error (MAPE). Penelitian bertujuan untuk meramalkan jumlah kasus ISPA pada anak di Kota Surabaya. Jenis penelitian adalah penelitian unobtrusive I nonreaktif. Peneliti mengkondisikan subjek tidak menyadari bahwa subjek sedang diteliti dan tmembuatnya tidak merasa terganggu. Data yang digunakan yaitu jumlah penyakit ISPA pada anak pada bulan januari 2014 hingga desember 2018. Data didapatkan dari laporan bulanan Unit Sistem Informasi Kesehatan (SIK) Dinas Kesehatan Kota Surabaya. Kesimpulan dari penelitian ini menunjukkan metode ARIMA memperoleh hasil model yang terbaik yaitu ARIMA $(2,1,2)$ dengan nilai MAPE yaitu 15,024. Hasil peramalan mengalami fluktuasi dan pola tren menurun pada kasus ISPA anak di Kota Surabaya. Bulan tertentu jumlah penyakit infeksi saluran pernafasan akut mengalami peningkatan yang signifikan diantaranya bulan Februari dan Maret.
\end{abstract}

Kata kunci: peramalan, time series, autoregressive integrated moving average, infeksi saluran pernafasan akut

\section{INTRODUCTION}

Prediction of future conditions is difficult to find out, since the factor of uncertainty is high. Forecasting is an estimation of an event that will occur in the future based on the past data. Forecasting is an activity in estimating events that will occur in the future (Widi, 2019).
Forecasting is a value estimation of the observed object/variable which value will be known after. The data is usually in the form of a time series (Pujadi, 2014) . Forecasting that is often used and developed until today is time series with a quantitative approach. Time series data is the data such as weekly, annual, monthly, and daily data (Gunaryati, 2018). 
Time series data are observations in the order of time from a quantitative approach and a collection of events that are taken in an unknown period (Aristyani and Sugiharti, 2015). Time series is a quantitative forecast method for analyzing pattern data from the past based on a time sequence. Time series, various types of methods can be used, including the ARIMA method or commonly called the BoxJenkins periodic series method, Decomposition, and Moving Average or Exponential (Dheviani and Hendikawati, 2018).

Data on the prevalence of morbidity and mortality in acute respiratory infections (ARI) in children cases every year is unstable. One effort to predict the unstable number of ARI cases in children is to predict the future conditions. Forecasting methods are needed to estimate the number of ARI cases. The forecasting method that is often used and developed until now is ARIMA.

The ARIMA method is often used because this method can estimate short-term, flexible, and follow data patterns by utilizing data from the past. Analysis of the ARIMA method can be used in estimating or predicting non-seasonal events, which is a model that does not involve seasonal factors. The seasonal model is a model that is influenced by seasonal factors or called Seasonal ARIMA or SARIMA (Darsyah, 2016).

The ARIMA method is also known as the Box-Jenkins Method. This method is very good in predicting the short-term event. Nevertheless, if it is used to forecast the long-term data then the accuracy will be decreased and tend to be flat. The selection of time series models needs to be considered data patterns. The forms of data are divided into several types, i.e. irregular (irregular motion), cycle, seasonal, and trend.

Seasonal variation is the pattern that occurs when there is a data series influenced by seasonal factors, usually often found in data on a weekly or monthly basis. Trend Pattern is a pattern that occurs when there is an increase in decline or graphs depicted a straight line (a curve) which can show the trend effect in the long term. Cycle Pattern is a pattern motion that exists around the trend line. Irregular/irregular patterns are random patterns. This pattern is difficult to model. Factors that cause this pattern is difficult to model because of natural disasters and chaos.
The ARIMA method has several types of models including ARMA, MA, ARIMA, and AR. The general form of ARIMA is ARIMA ( $p$, $\mathrm{d}, \mathrm{q})$. Q denotes the Moving Average, $\mathrm{p}$ denotes an Autoregressive order, while d denotes an Integrated order (Hadiansyah, 2017). The general equation of Autoregressive (p), states the following formula:

$Y t=\theta 1 Y t-1+\theta 2 Y t-2+\theta 3 Y t-$ $3+\ldots+\theta p Y t-p+e t$

Information:

$\mathrm{Yt}=$ Dependent variable

Yt $-1, Y t-2, Y t-3, \ldots, Y t-p=L a g$ of the dependent variable

$\Theta 1, \Theta 2, \Theta 3, \ldots ., \Theta p=$ autoregressive parameter et $=$ Error $/$ residual

The general formula in the Moving Average (MA) (q) model is stated as follows:

$$
\begin{gathered}
Y t=e t-\theta 1 \text { et }-1-\theta 2 \text { et }-2 \\
-\theta 3 \text { et }-3-\ldots-\theta q \text { et }-q
\end{gathered}
$$

Information:

$\mathrm{Yt}=$ dependent variable

et-1, et-2, et-3, ..., et-q = Lag of error

$\Theta 1, \Theta 2, \Theta 3, \ldots ., \Theta q=$ Moving average parameter

et $=$ Error $/$ residual $/$ error

The ARMA model is a combination of models from $\mathrm{AR}$ and MA, the form of the equation is:

$$
\begin{aligned}
& Y t=\theta 1 Y t-1+\theta 2 Y t-2+\theta 3 Y t-3+ \\
& \ldots+\theta p Y t-p+e t-\theta 1 \text { et }-1-\theta 2 \text { et }- \\
& 2-\theta 3 \text { et }-3-\ldots-\theta q \text { et }-q
\end{aligned}
$$

Information:

$\mathrm{Yt}=$ Dependent variable / predicted variable

$\mathrm{Yt}-1, \mathrm{Yt}-2, \ldots, \mathrm{Yt}-\mathrm{p}=\mathrm{Lag}$ of the dependent variable

et -1 , et $-2, \ldots$, et $-\mathrm{q}=\mathrm{Lag}$ of errors

$\Theta \mathrm{p}=$ autoregressive parameter

$\Theta q=$ Moving average parameter

et $=$ Error $/$ residual / error

The ARIMA model is a mixture of the ARMA model, then experiences differencing orders d. the general form is ARIMA (p, d, q). The form of the equation is: 
$\theta p(B P)(1-B) d Y t=C+\Theta q(B q) a t$

Information:

$\mathrm{Yt}=$ The dependent variable from time to $\mathrm{t}$

$\mathrm{Q}=$ Order of the MA model

$\mathrm{C}=$ Constant

$\mathrm{P}=$ Order autoregressive model

at $=$ Error $/$ residual at time $\mathrm{t}$

$\mathrm{d}=$ amount of defferentiation

Forming a time series model with the ARIMA method requires an assumption that must be met. The assumption is with the stationarity of data (the data is stationary). The time series data assumption is said to be eligible if the stationary invariance and means depends on the time difference (Wanto, 2016).

There are two kinds of stationary data, namely stationary means (average) and stationary variance. If the data is not stationary/consistent at an average, then do it with differencing. Data is not stationary in the variant must do by transforming.

If the data is stationary, then it has several stages. The stages of model formation are as follows: parameter identification, model estimation, diagnostic model, overfitting model and forecasting: Model Identification, the first step of the identification model is to look at the time series data plot. The data plot functions to find out the stationarity of the data (the data is stationary).

If the data does not appear to be stationary in the variant, then Transformation is needed. Data that is not stationary on average do the differencing. Stationary data is then analyzed based on the plot of the Partial Autocorrelation Function (PACF) and Autocorrelation Function (ACF) (Salwa, 2018).

AR, MA, Seasonal, and Non-Seasonal parameters can be used in the estimation model but must be determined accurately through hypothesis testing. Hypothesis testing is done to see the significance of a parameter (Darsyah, 2016).

Diagnostic Model was done by seeing what is sufficient enough from the model obtained. An adequate model can be seen in the analysis of error values. Diagnostic model is performed to carry out residual examinations with LjungBox test statistics (Selitubun, Lesnussa and Kondolembang, 2017).

Overfitting Model was done to get another model. After getting the model, then see the Ljung-Box significance and statistical test. The model can be used in forecasting if it matches both tests. If it does not match the significance test and the Ljung-Box test, other models cannot be used.

The best model has been obtained from the estimation test results of the model and diagnostic models. Forecasting is the next step in making predictions using the best model. Prediction can be done following the desired forecasting period.

The disease that has always been a major health problem in Indonesia is acute respiratory infections (ARI) since the number of the cases are still quite high. ARI causes death and certain degree of pain. Every year, there are 4 million people who die from mild ARI (Syahidi, 2016).

ARI often affects adults and children and possibly cause death. This disease is more susceptible to infect children under 5 years old. The highest characteristic was found to be $<5$ years old at $25.8 \%$ (Dongky and Kadrianti, 2016). According to the 2018 Basic Health Research Report (Riskesdas), the characteristics of a high age group are cases of age groups 1-4 years, there are $13.7 \%$ and ages 5-14 years are 10.6\% (Indonesian Ministry of Health, 2018).

The prevalence of ARI in East Java reached the highest rate, including in 2012 when there were 75,124 cases while from 2013 to 2014 there were 78,256 cases (Mayasari, 2015). According to the East Java Provincial Health Office in 2017, there were 86,358 cases of children pneumonia (East Java Provincial Health Office, 2017).

According to the health profile data of the Surabaya City Health Office in 2015, there were 4,018 cases of acute respiratory infections in children. In 2016 there was a research finding of 3,925 of the estimated children suffering from pneumonia. According to the data from the Surabaya City Health Office in 2017, there were 5,534 cases found of the estimated children which caused mild ARI (pneumonia) (Surabaya City Health Office, 2017).

Factors that can lead to ARI occurrence are called characteristic factors, agent factors, and environmental factors. The characteristic factors including age, sex, nutritional status, exclusive breastfeeding, and immunization status. The agent factors including viruses and bacteria, while for the environment including air pollution, lighting, ventilation windows, humidity, and dense residential areas (Christi, Rahayuning and Nugraheni, 2015). 
One of the main problems with ARI is difficulty in breathing (dyspnea). Dyspnea is a subjective symptom of the patient's desire to increase breathing air. Dyspnea can cause hypoxia (lack of oxygen at the tissue level) (Ananda, 2018). Symptoms that are often experienced by ARI patients including fever, sore throat, runny nose, dry cough or phlegm, and these symptoms usually occur over the past month (Wahyuningsih, Raodhah and Basri, 2017).

Based on these considerations, the researcher used ARIMA time series method forecasting since there are historical data. ARIMA method is used to determine the best model of the number of ARI cases in the city of Surabaya. ARIMA method is also used in generating forecasting from ARI cases in children in the future.

\section{METHODS}

This type of research is unobtrusive/nonreactive research. The researcher conditioned the subjects to not being aware that the subject is being studied and therefore, left the subject uninterrupted. Nonreactive research is usually used for secondary data. The study used monthly report data for all ARI cases in children in Surabaya from 2014 to 2018 recorded in the Surabaya City Health Office.

\section{RESULT}

\section{Overview of ARI in Children in Surabaya}

Forecasting is an event estimation that occurs using time series data based on past values. Research data that was used is from cases of Acute Respiratory Infection in children, using secondary data from the SIK Unit of the Surabaya City Health Office.

ARI is a disease that causes infection of the upper respiratory tract (including Orthomyxovirus, Paramyxovirus, Metamyxovirus, Adenovirus, and others). Infection in the lower respiratory tract is caused by fungus, bacteria, and viruses. Bacteria that cause respiratory infections including Pneumococcus, Streptococcus, Haemophilus, and Corynebacterium diphtheriae. Fungi that cause ARI such as Aspergillus, Histoplasma, capsulatum, fichomycetes. Data for cases of
ARI in children in Surabaya obtained in 20142018, as follows:

Table 1. Number of ARI Cases in Children in Surabaya

\begin{tabular}{lccccc}
\hline \multirow{2}{*}{ Month } & \multicolumn{5}{c}{ Year } \\
\cline { 2 - 6 } & $\mathbf{2 0 1 4}$ & $\mathbf{2 0 1 5}$ & $\mathbf{2 0 1 6}$ & $\mathbf{2 0 1 7}$ & $\mathbf{2 0 1 8}$ \\
\hline January & 175 & 168 & 148 & 215 & 356 \\
February & 262 & 243 & 232 & 299 & 349 \\
March & 326 & 275 & 240 & 396 & 471 \\
April & 422 & 259 & 238 & 394 & 427 \\
May & 364 & 192 & 277 & 357 & 382 \\
June & 274 & 167 & 228 & 292 & 340 \\
July & 210 & 185 & 155 & 330 & 494 \\
August & 241 & 302 & 254 & 360 & 645 \\
September & 217 & 230 & 300 & 394 & 462 \\
October & 223 & 224 & 310 & 399 & 475 \\
November & 188 & 219 & 295 & 369 & 473 \\
December & 207 & 208 & 250 & 322 & 414 \\
\hline Amount & 3109 & 2672 & 2927 & 4127 & 5288 \\
\hline Source: & Health Information System (HIS) & of \\
& Surabaya City Health Office &
\end{tabular}

Based on Table 1, cases of ARI in children in Surabaya revealed the results that the number of cases of ARI in children in the city of Surabaya experienced fluctuations and patterns of increasing trends. 2018 is an increase in cases of ARI in children in the city of Surabaya. The pattern of the number of ARI cases is shown as follows:

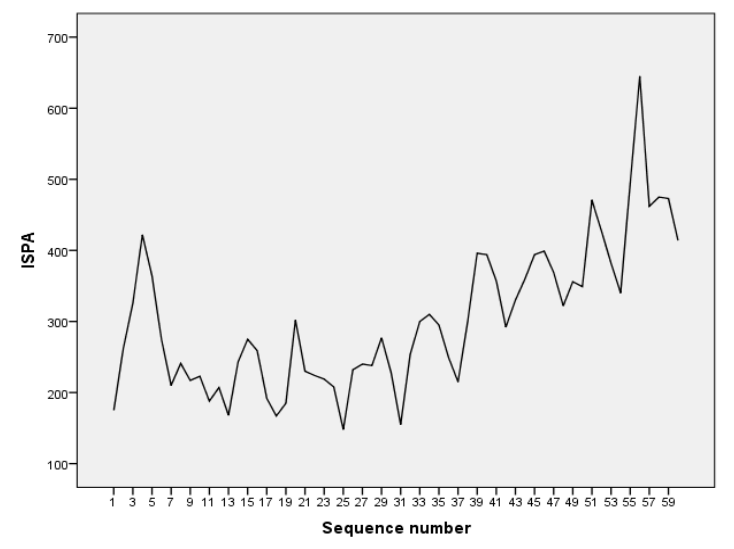

Figure 1. Plot Number of ARI Cases in Children in Surabaya (2014-2018)

\section{ARI Model Using the ARIMA Method}

Modelling consists of several steps, i.e. stationary inspection, application of provisional models, estimation of model parameters, diagnostic models, overfitting, and forecasting. The first step in forming the model is data 
stationarity (to see whether the data is stationary). Stationarity is divided into two: invariance and average.

Based on Figure 1, data plot of ARI in children in Surabaya shows non-stationary data in means. Data that is not stationary is done by differencing (1). The following patterns have become stationary after differencing (1):

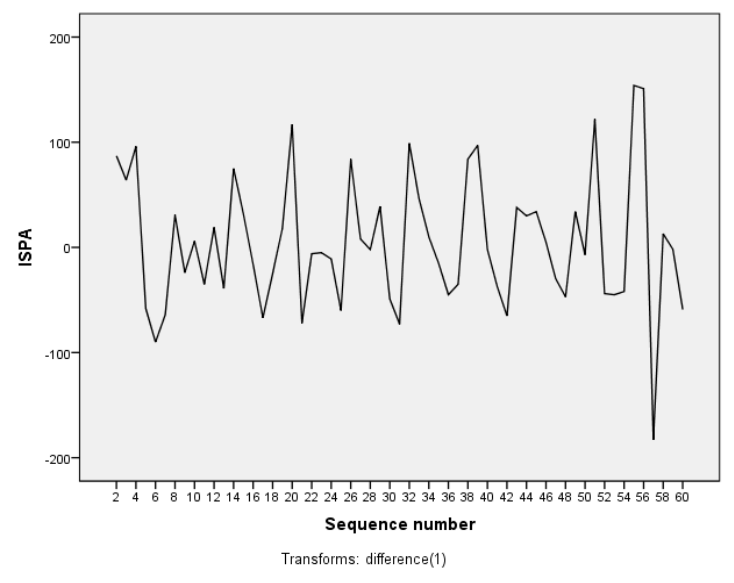

Figure 2. Plot Number of UTI Cases after in Differencing (1)

Based on Figure 2, plots of the number of ARI cases after differencing (1), the results of the data are stationary. The data is classified as stationary on average and variants if the data is stable from point 1 to point 60 . If the data has been stationary, then it can be proceeded to identify the model.

The second step is done after the data has been stationary, namely identifying the right ARIMA model (p, d, q) using a plot Partial Autocorrelation Function and Autocorrelation Function. The data of ARI disease in children in Surabaya which has been stationary after differencing order 1 , so that the value of $d$ is value 1 . The ARIMA model is $(p, 1, q)$. The following figure is displayed in the plot of the
Partial Autocorrelation Function and Autocorrelation Function:
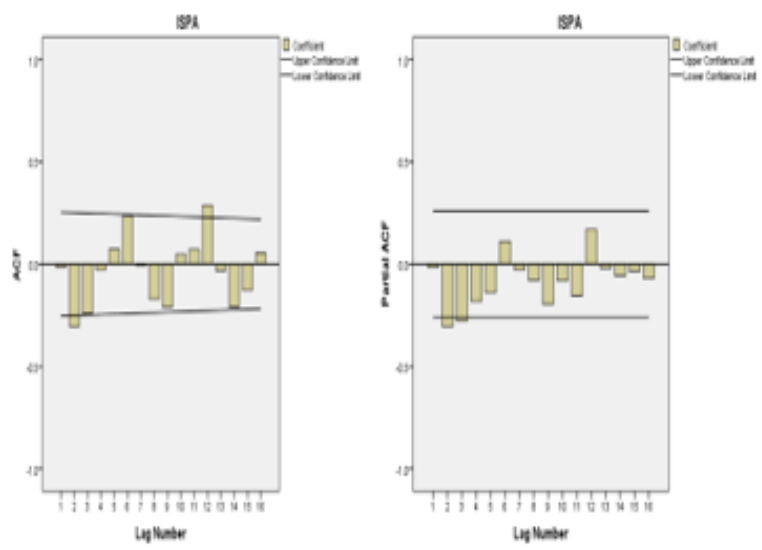

Figure 3. Plot Partial Autocorrelation Function and Autocorrelation Function

Based on Figure 3, the PACF and ACF plots obtained the following interim models: ARIMA $(0,1,2), \quad$ ARIMA $(1,1,1), \quad(1,1,2)$, $(2,1,0),(2,1,1)$ and $(2,1,2)$. The third step is model estimation. Model estimation was done after obtaining a temporary model. The model obtained from the estimation is ARIMA $(2,1,2)$, $(1,1,2),(0,1,2),(2,1,0),(2,1,1)$ and $(1,1,1)$, then significance test was performed. The significance test can be displayed on Table 2 .

Based on Table 2 the estimated model obtains results that the model considered significance if the value of Sig. $<\alpha(\alpha=0.05)$. Temporary models that match with ARIMA are $(2,1,1),(2,1,2)$, and $(0,1,2)$. Significant models were then performed, diagnostic models.

The fourth step is the diagnostic model. The diagnostic model was performed by looking at White Noise. Error/residual is said to be White Noise if the value of Ljung-Box $Q>\alpha$ $(\alpha=0.05)$. The White Noise Test can be seen on Table 3 .

Table 2. Model Estimation without Constants

\begin{tabular}{|c|c|c|c|c|c|}
\hline \multirow{2}{*}{$\begin{array}{l}\text { ARIMA } \\
\text { Model }\end{array}$} & \multicolumn{4}{|c|}{ Sig. / P-value } & \multirow{2}{*}{$\begin{array}{c}\text { Conclusion of Significant } \\
\text { Parameters }\end{array}$} \\
\hline & AR (1) & AR (2) & MA (1) & MA (2) & \\
\hline$(0,1,2)$ & - & - & 0.044 & 0.003 & Significant \\
\hline$(1,1,1)$ & 0.026 & - & 0.000 & - & Significant \\
\hline$(1,1,2)$ & 0.597 & - & 0.254 & 0.87 & Not significant \\
\hline$(2,1,0)$ & 0.854 & 0.017 & - & - & Not significant \\
\hline$(2,1,1)$ & 0.008 & 0.009 & 0.000 & - & Significant \\
\hline$(2,1,2)$ & 0.000 & 0.000 & 0.000 & 0.014 & Significant \\
\hline
\end{tabular}


Table 3. Diagnostic Model

\begin{tabular}{ccl}
\hline ARIMA Model & Ljung-Box Q (18) & Information \\
\hline$(0,1,2)$ & 0.101 & White Noise \\
$(2,1,1)$ & 0.645 & White Noise \\
$(2,1,2)$ & 0703 & White Noise \\
\hline
\end{tabular}

Table 4. Overfitting Model

\begin{tabular}{ccccccccc}
\hline ARIMA & \multicolumn{9}{c}{ Sig. / P-value } & Conclusion \\
\cline { 2 - 8 } Model & AR (1) & AR (2) & AR (3) & MA (1) & MA (2) & MA (3) & MA (6) & \\
\hline$(2,1,3)$ & 0.000 & 0.000 & - & 0.012 & 0.271 & 0.357 & - & Not significant \\
$(2,1,6)$ & 0.000 & 0.000 & - & 0.000 & 0.338 & 0.689 & 0.389 & Not significant \\
$(3,1,2)$ & 0.009 & 0.000 & 0.336 & 0.000 & 0.001 & - & - & Not significant \\
$(3,1,3)$ & 0.607 & 0.764 & 0.000 & 0.498 & 0.038 & 0.044 & - & Not significant \\
\hline
\end{tabular}

Based on Table 3, the diagnostic model obtained the results of the model that have been achieved. White Noise is ARIMA $(0,1,2)$, $(2,1,1)$, and $(2,1,2)$. In the ARIMA model $(1,1,1),(1,1,2)$ and $(2,1,0)$ there is no white noise. Therefore, the three models can fulfill the requirements to be the best parameters including ARIMA $(2,1,1),(2,1,2)$, and $(0,1,2)$.

The fifth step is overfitting model. Overfitting model one to get another model. Overfitting is used by changing the moving average and autoregressive to ARIMA. Overfitting gave rise to models namely ARIMA $(3,1,2),(3,1,3),(2,1,3)$, and $(2,1,6)$. Another model was obtained, then analyzed using the significance test. Overfitting model can be displayed on Table 4.

Based on Table 4, the overfitting model results which gave rise to other models cannot be used because they did not match the requirements i.e. the model is insignificant. Temporary models that matched the requirements of the best models, i.e. ARIMA $(0,1,2),(2,1,1)$ and $(2,1,2)$. The model that appeared cannot be used because it was not significant.

The ARIMA interim models have been determined and there were three ARIMA models matched the requirements of the best models. Only one best model was chosen in predicting the number of ARI cases in children in Surabaya. The step to determine the best model is to look at the smallest error rate. Measuring errors is one of them by looking at the value of MAPE. The smaller the MAPE value, the better the model. MAPE values can be displayed on Table 5 .

Based on Table 5 the MAPE values of the three models are ARIMA $(2,1,2),(0,1,2)$ and
$(2,1,1)$. The temporary model that is qualified to be the best is the ARIMA model $(2,1,2)$ because it has a small MAPE value of 15,054 . The ARIMA model $(2,1,2)$ can be used to predict the number of ARI cases in children in Surabaya. The model equation is as follows:

$\mathrm{Xt}=0.871 \mathrm{Xt}-1-0.751 \mathrm{Xt}-2+$ et $-1,127$ et $-1+$ 0.548 et- 2

The sixth step is forecasting or prediction. The best ARIMA forecasting model results on ARI cases in children in Surabaya is ARIMA $(2,1,2)$. Forecasting of the number of ARI cases in Surabaya in 2019 can be displayed on Table 6.

Table 5. MAPE Value

\begin{tabular}{cc}
\hline ARIMA Model & MAPE \\
\hline$(0,1,2)$ & 15,804 \\
$(2,1,1)$ & 15,421 \\
$(2,1,2)$ & 15,054 \\
\hline
\end{tabular}

Table 6. ARI Forecasting Results in Children in Surabaya City in 2019

\begin{tabular}{lc}
\hline \multicolumn{1}{c}{ Month } & Forecasting \\
\hline January & 467 \\
February & 509 \\
March & 505 \\
April & 470 \\
May & 443 \\
June & 445 \\
July & 468 \\
August & 486 \\
September & 484 \\
October & 470 \\
November & 458 \\
December & 459 \\
\hline
\end{tabular}


Based on Table 6, the forecast for Pediatric ARI in Surabaya fluctuates and the trend patterns decrease. The highest number of cases occurred in February and March while the lowest number occured in May and June.

\section{DISCUSSION}

The research used a time series. Time series is an analysis of the relationship between independent variables and dependent variables (Azizah, 2015). Time series has a variety of methods that can be used in the analysis. Analysis of the method used is the ARIMA method. There are several stages in ARIMA including stationarity, parameter identification, estimation, diagnostic, overfitting, and forecasting.

Data stationarity was carried out before forming the model. Data stationarity functions to see whether stationary data is invariants and averages. Data not stationary on average must be differentiated (differencing). Data that is not stationary in variance performs by transforming to become stationary.

Data on ARI in children in Surabaya was considered not stationary on average so that the differencing was done (1). Respiratory disease data in children in Surabaya after differencing (1) appear to become stationary invariance and on average. Differencing (1) is data that is used as a model for forecasting with the difference in actual data. The difference in actual data performed once has been obtained by stationary data patterns so that it can be used to make ARIMA prediction models.

Model identification applied by looking at PACF and ACF charts. PACF is used to determine the AR (p) model by looking at the lags that drop exponentially. In the ACF chart, the function is to analyze MA (q) to look for lags that fall exponentially. ACF plot has cut off value / cut second lag and 3rd lag then MA value is 2 and 3. PACF plot has cut off value/cut at second lag and third lag then AR value is 2 and 3 The model obtained in the case of ARI in children in Surabaya after differencing and seeing the ACF and PACF plots was obtained, namely the ARIMA model $(2,1,1),(2,1,0)$, $(2,1,2),(0,1,2),(1,1,2)$, and $(1,1,1)$.

Estimation is applied to determine the exact model estimates through hypothesis testing/significance tests (Sinaga, 2018). Estimation functions to see which models are significant. Analysis of significant models uses statistical application software assistance, if the model has a p-value $<0.05$. ARIMA models that are already significant are the ARIMA models $(0,1,2),(2,1,1)$ and $(2,1,2)$ without constants.

The diagnostic model is used to determine whether the model can be used or cannot be used through the Ljung-Box test (Munawaroh, 2010). The diagnostic model is used to see if the temporary model that has been obtained is adequate or not. The diagnostic model is performed by testing white noise. White noise testing results in a decent model and meet the requirements of the best model are the ARIMA $(2,1,2),(2,1,1)$, and $(0,1,2)$ models. ARIMA models $(2,1,0),(1,1,1)$, and $(1,1,2)$ do not have white noise.

The best models of estimation and diagnostic results obtained by three models, namely ARIMA $(2,1,2),(0,1,2)$ and $(2,1,1)$. but only one model is used in predicting the number of ARI cases in children in the city of Surabaya. Determining the best model can be seen through the level of error (error). The level of error can be measured in various ways, one of which is through Mean Absolute Percentage Error (MAPE).

MAPE assumption if the value is small, the better the forecasting model. The results of the MAPE value of the three models, namely ARIMA $(0,1,2)$ amounted to 15,804 which means the error/error rate of forecasting results in the number of ARI cases in children in the city of Surabaya with the ARIMA method was $15.80 \%$. The ARIMA model $(2,1,1)$ is 15,421 which means the forecasting result error in the number of ARI cases in children in Surabaya using the ARIMA method is $15.42 \%$. The ARIMA model $(2,1,2)$ is 15,054 which means the forecasting result error in the number of ARI cases in children in Surabaya using the ARIMA method is $15.05 \%$.

The conclusion from the three models getting the smallest MAPE value is ARIMA $(2,1,2)$. Forecasting results obtained a downward trend in the number of cases. Certain months experienced a high increase in ARI cases, including February and March. The model is the best model that can be used to predict the number of ARI in children in Surabaya in one year. 


\section{CONCLUSIONS AND SUGGESTIONS}

\section{Conclusion}

The results of this study indicated the number of ARI in children in Surabaya from 2014 to 2018 experiencing fluctuations and increasing trend patterns. Analysis using the ARIMA method obtained the best model of ARI cases in children in Surabaya, namely the ARIMA model $(2,1,2)$ without constants. The results of the prediction of ARI cases in children in Surabaya in 2019 occurred fluctuations and a downward trend, in certain months experiencing an increase including February and March.

\section{Suggestion}

Forecasting using the ARIMA method can be used by government institutions to establish policies as a planning process for preventing the growth of acute respiratory tract infections that infect adults and children.

\section{REFERENCES}

Ananda, R.R., 2018. Hubungan antara Lung Capacity dengan Derajat Dyspnea sebagai Preventif ISPA Berulang. JOM FKp, 5 (2), pp.795-804.

Aristyani, Y., and Sugiharti, E., 2015. Peramalan Indeks Harga Saham Gabungan (IHSG) dengan Metode Fuzzy Time Series Markov Chain. Jurnal MIPA, 38 (2), pp.186-196.

Azizah, A.F.N., 2015. Peramalan Migrasi Masuk Kota Surabaya Tahun 2015 dengan Metode Double Moving Average dan Double Exponential Smoothing Brown. Jurnal Biometrika dan Kependudukan, 4 (2), pp.172-180.

Christi, H., Rahayuning, D., and Nugraheni, S.A., 2015. Faktor-Faktor yang Berhubungan dengan Kejadian ISPA pada Bayi Usia 6-12 Bulan yang Memiliki Status Gizi Normal. Jurnal Kesehatan Masyarakat, 3 (2), pp. 107-117.

Darsyah, M. Y., 2016. Model Terbaik Arima dan Winter pada Peramalan Data Saham Bank. Stasistika, Vol. 4 (1), pp. 30-38.

Dheviani, S. and Hendikawati, P., 2018. Peramalan Banyaknya Penumpang di Bandar Udara Internasional Ahmad Yani Semarang dengan Mempertimbangkan Special Event. Prisma, 1 (2018), pp.434444.
Dongky, P., and Kadrianti, 2016. Faktor Risiko Lingkungan Fisik Rumah dengan Kejadian ISPA Balita di Kelurahan Takatidung Polewali Mandar. Unnes Journal of Public Health, 5 (4), pp. 324-329.

Gunaryati, A., 2018. Perbandingan MetodeMetode Peramalan Statistika untuk Data Indeks Harga Pangan. Jurnal String, 2 (3), pp.241-248.

Hadiansyah, F., 2017. Prediksi Harga Cabai dengan Pemodelan ARIMA. Ind. Journal on Computing. 2 (1), pp.71-78.

Indonesian Ministry of Health, 2018. Laporan Riset Kesehatan Dasar (RISKESDAS) 2018. Jakarta.

Mayasari, E., 2015. Analisis Faktor Risiko Kejadian ISPA Ditinjau dari Status Rumah di Wilayah Kerja Puskesmas Kota Wilayah Utara Kota Kediri. Jurnal IKESMA, 11 (1), pp. 161-171.

Munawaroh, S., 2010. Analisis Model Arima Box-Jenkins pada Data Fluktuasi Harga Emas. Thesis. Maulana Malik Ibrahim State Islamic University of Malang.

Pujadi, T., 2014. Model Pemesanan Bahan Baku Menggunakan Peramalan Time Series dengan CB Predictor. ComTech, 5 (2), pp. 954-962.

Surabaya City Health Office, 2017. Profil Kesehatan Kota Surabaya 2017. Surabaya.

East Java Provincial Health Office, 2017. Profil Kesehatan Provinsi Jawa Timur 2017. Surabaya.

Salwa, N., Tatsara, N., Amalia, R., Zohra, A.F., 2018. Peramalan Harga Bitcoin Menggunakan Metode ARIMA (Autoregressive Integrated Moving Average). Journal of Data Analysis, 1 (1), pp. 21-31.

Selitubun, E., Lesnussa, Y.A., and Kondolembang, F., 2017. Pemodelan Arima untuk Prediksi Kenaikan Muka Air Laut dan Dampaknya terhadap Luas Sebaran Rob di Kota Ambon. Matematika dan Pendidikan Matematika, 2 (1), pp. 5867.

Sinaga, E., 2018. Perancangan Aplikasi Prediksi Jumlah Kelulusan Mahasiswa dengan Metode Auto Regressive Integrated Moving Average (ARIMA). Majalah Ilmiah INTI, 13 (3), pp. 308-313.

Syahidi, M. H., 2016. Faktor-Faktor yang Mempengaruhi Kejadian Infeksi Saluran Pernapasan Akut (ISPA) pada Anak Berumur 12-59 Bulan di Puskesmas 
Kelurahan Tebet Barat, Kecamatan Tebet, Jakarta Selatan, Tahun 2013. Jurnal Epidemiologi Kesehatan Indonesia, 1 (1), pp.23-27.

Wahyuningsih, S., Raodhah, S., and Basri, S., 2017. Infeksi Saluran Pernafasan Akut (ISPA) pada Balita di Wilayah Pesisir Desa Kore Kecamatan Sanggar Kabupaten Bima. HIGIENE: Jurnal Kesehatan Lingkungan, 3 (2), pp. 97-105.
Wanto, K., 2016. Analisis Intervensi Data Deret Waktu untuk Peramalan Pendapatan Domestik Bruto Indonesia. Thesis. Universitas Negeri Jakarta.

Widi, W., 2019. Analisa Peramalan Winter's Exponential Smoothing Brown Dibandingkan dengan Autoregressive Integrated Moving Average pada Data Jumlah Kejadian Hipertensi. Jurnal Ilmu Kesehatan, 4 (1), pp. 1-10. 